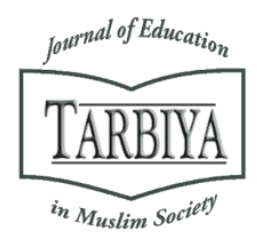

Available online at TARBIYA: Journal of Education in Muslim Society Website:

http://journal.uinjkt.ac.id/index.php/tarbiya

TARBIYA: Journal of Education in Muslim Society, 7(1), 2020, 1-15

\title{
A CRITICAL INVESTIGATION OF ENGLISH SUBJECT TEACHING AT TWO TYPES OF MADRASAS IN BANGLADESH
}

\author{
Azam Md Golam \\ Hiroshima University, Japan \\ E-mail: mohsin6857@gmail.com
}

Received: $28^{\text {th }}$ October 2019; Revised: $28^{\text {th }}$ May 2020; Accepted: $28^{\text {th }}$ June 2020

\begin{abstract}
This study aims to survey the secular subject, teaching of English, and learning in Qawmi Madrasas at grade 8 and Alia Madrasas in Bangladesh. Ethno-methodological surveys have been conducted in 2018 of the Southern region of Bangladesh, particularly among the students, teachers, and principals of eight Qawmi madrasas and five Alia madrasas. Findings revealed that Qawmi Madrasas do not have a conducive English learning environment for grade 8 level, class duration and schedule, teachers' salaries, as well as resources, found inadequate as opposed to the Alia religious schools. Unlike Qawmi Madrasas (Independent Islamic seminaries), Alia Madrasas (reformed religious schools) have so far, the privileges. Interviewees reported the immediate need for teacher training in English language learning for Qawmi religious schools. Moreover, students in the Qawmi schools also claimed that the resources used in the classroom, such as English textbooks should be employed more effectively. This research also found that internal and external factors forced them to include the secular subject, English in particular in their syllabi. Previous studies have focused mainly on religious schools through a sociological lens. However, this study addresses the secular subject, English teaching at unsecular religious schools in Bangladesh; hence, it provides values for avid readers, researchers and those who are involved in future studies of this country.
\end{abstract}

Keywords: Non-religious subject; curriculum; religious schools; Madrasas; Bangladesh

\section{Abstrak}

Penelitian ini bertujuan untuk mensurvei mata pelajaran sekuler, pengajaran bahasa Inggris, dan pembelajaran di Madrasah Qawmi kelas 8 dan Madrasah Alia di Bangladesh. Survei etno-metodologi telah dilakukan pada tahun 2018 di wilayah selatan Bangladesh, khususnya di antara siswa, guru, dan kepala sekolah dari delapan madrasah Qawmi dan lima madrasah Alia. Temuan mengungkapkan bahwa Madrasah Qawmi tidak memiliki lingkungan belajar bahasa Inggris yang kondusif untuk tingkat kelas 8, durasi dan jadwal kelas, gaji guru, serta sumber daya, ditemukan tidak memadai dibandingkan dengan sekolah agama Alia. Berbeda dengan Madrasah Qawmi (seminari Islam Mandiri), Madrasah Alia (madrasah yang direformasi) sejauh ini memiliki keistimewaan. Orang yang diwawancarai melaporkan perlunya segera pelatihan guru dalam pembelajaran bahasa Inggris untuk sekolah agama Qawmi. Selain itu, siswa di sekolah Qawmi juga mengklaim bahwa sumber daya yang digunakan di kelas, seperti buku teks bahasa Inggris harus digunakan dengan lebih efektif. Penelitian ini juga menemukan bahwa faktor internal dan eksternal memaksa mereka untuk memasukkan mata pelajaran sekuler, khususnya bahasa Inggris dalam silabus mereka. Studi sebelumnya berfokus terutama pada sekolah agama melalui lensa sosiologis. Namun, penelitian ini membahas subjek sekuler, pengajaran bahasa Inggris di sekolah agama unsecular di Bangladesh; karenanya, ini memberikan nilai bagi pembaca, peneliti dan mereka yang terlibat dalam studi masa depan negara ini.

Kata kunci: Mata pelajaran non-agama; kurikulum; sekolah agama; Madrasah; Bangladesh

How to Cite: Golam, A. Md. (2020). A Critical Investigation of English Subject Teaching at Two Types of Madrasas In Bangladesh. TARBIYA: Journal of Education in Muslim Society, 7(1), 1-15.

doi:10.15408/tjems.v7i1.13041.

Permalink/DOI: http://dx.doi.org/10.15408/tjems.v7i1.13041

TARBIYA: Journal of Education in Muslim Society, P-ISSN: 2356-1416, e-ISSN: 2442-9848

This is an open access article under CC-BY-SA license (https://creativecommons.org/licenses/by-sa/4.0/) 


\section{Introduction}

Madrasa (Islamic school) is an Arabic word. It involves the teaching of a set of curriculum beginning with the process of hifz (memorization of Holy Quran) and learning to higher studies in Islamic theology (Bano, 2010). The religious Madrasa education in Bangladesh comprises both state regulated private Madrasas as well as self-governing Madrasas. The former are known as Alia Madrasas, where, alongside Islamic teaching, secular education is also provided (Asadullah \& Chaudhury, 2010). The latter, known as Qawmi Madrasas, concentrate on Islamic education. The differences between Alia and Qawmi madrasa mentioned in Table 1.

Table 1. Differences between Alia and Qawmi madrasa education system

\begin{tabular}{|c|c|}
\hline Alia madrasa & Qawmi madrasa \\
\hline $\begin{array}{l}\text { Integrated secular subjects } \\
\text { in their syllabi up to } \\
\text { undergraduate level }\end{array}$ & $\begin{array}{l}\text { Introduced general subjects } \\
\text { up to grade } 8 \text {. }\end{array}$ \\
\hline Imparted secular subjects in & Introduced general subjects \\
\hline the 1980s. Recognized & in 2012. Recognized only \\
\hline $\begin{array}{l}\text { ranging from } \\
\text { (Secondary) to } \\
\text { (Master's) level. }\end{array}$ & $\begin{array}{l}\text { Dawra-e-Hadith (Master's } \\
\text { level) in } 2018 \text { by education } \\
\text { law. }\end{array}$ \\
\hline $\begin{array}{l}\text { Reformed and follow } \\
\text { government } \\
\text { guidelines }\end{array}$ & $\begin{array}{l}\text { Orthodox and completely } \\
\text { independent, follow } \\
\text { Deobandi in India. }\end{array}$ \\
\hline Regulate by Bangladesh & Bangladesh Qawmi \\
\hline $\begin{array}{l}\text { Madrasa Education Board, } \\
1979 \text { and Islamic Arabic } \\
\text { University, 2013. }\end{array}$ & $\begin{array}{l}\text { Madrasa Education Board, } \\
1978 .\end{array}$ \\
\hline $\begin{array}{l}\text { Survived on government } \\
\text { funding. }\end{array}$ & $\begin{array}{l}\text { Survived on community, } \\
\text { overseas donation and } \\
\text { student fees. }\end{array}$ \\
\hline $\begin{array}{l}\text { Graduate can access to } \\
\text { public university and civil } \\
\text { service. }\end{array}$ & $\begin{array}{l}\text { Gradaute cannot access to } \\
\text { public university and civil } \\
\text { service. }\end{array}$ \\
\hline
\end{tabular}

Muslim learners study in these two categories of Islamic seminaries. The number of Qawmi Madrasas in Bangladesh so far is 26, 671, while the Alia Madrasas is 9,303 (BANBASE, 2018). Details mentioned in Table 2.

Studies on English education at Madrasas in general, Qawmi in particular and the subsequent post-schooling outcomes are, however, rarely studied in Bangladesh. In particular, none of the extant studies directly focus on the effectiveness of English teaching and learning in Bangladesh. Little is known on English teaching in the context of Qawmi and Alia Madrasas so far. However, Madrasas are mushrooming in the education system in Bangladesh. The modernization arrangement of 1980 progressively introduced secular subjects, for instance, English, Mathematics, alongside topics related to Islam and languages in the syllabi of Islamic schools, in Alia Madrasas to be specific (Asadullah \& Chaudhury, 2010) while Qawmi Madrasas' opened the process of secularisation by familiarizing the English language, for example, in 2012.

English language and secularisation have a good relationship as the English language holds the dominant position and are spreading across increasingly large areas of knowledge (Held et al.,1999) in operationalizing the secularisation process. Through modernization efforts, madrasas can arguably be associated with some interlinked values; for instance, reason, scientism, and freedom. The ultimate notion of this study is the transformation of knowledge between the religious and secular forms of the Alia and Qawmi madrasa education system, which the author depicted later in the analytical segment in details.

Quality English teaching and learning at Islamic seminaries are sub-standard, and below expected grade, thus affecting the competitiveness of learners graduating from these seminaries, Qawmi students to be specific, who realize it challenging to access higher education at public universities as well as to find government job in Bangladesh. Private, English medium schools continue to be seen as a pathway to white-collar employment, but also use English as an international and not just colonial language, coexisting alongside public, 
vernacular language and religious schools for the poor, seen as sufficient for blue-collar and manual work (Munshi \& Resenzweig, 2003).

Table 2. Statistical information

\begin{tabular}{|c|c|c|c|c|c|c|c|}
\hline \multirow{2}{*}{$\begin{array}{l}\text { Madrasas/Sch } \\
\text { ools }\end{array}$} & \multirow{2}{*}{ Numbers } & \multicolumn{2}{|c|}{ Students } & \multirow{2}{*}{$\begin{array}{c}\text { Total } \\
\text { students }\end{array}$} & \multicolumn{2}{|c|}{ Teachers } & \multirow{2}{*}{\begin{tabular}{|c|} 
Total \\
Teachers \\
\end{tabular}} \\
\hline & & Boys & Girls & & Male & Female & \\
\hline Qawmi & 26,671 & $1,058,636$ & 339,616 & $1,398,252$ & 66,902 & 6,829 & 73,731 \\
\hline$(\%)$ & 13.73 & 5.88 & 1.87 & 3.87 & 3.76 & 1.35 & 3.23 \\
\hline Alia & 9,303 & $1,102,815$ & $1,350,549$ & $2,453,364$ & 98,849 & 14,912 & 113,761 \\
\hline$(\%)$ & 4.79 & 6.13 & 7.43 & 6.78 & 5.56 & 2.94 & 4.98 \\
\hline $\begin{array}{c}\text { General } \\
\text { School }\end{array}$ & 158,303 & $15,835,357$ & $16,476,374$ & $32,311,731$ & $1,612,609$ & 484,737 & $2,097,346$ \\
\hline$(\%)$ & 81.48 & 87.99 & 90.70 & 89.35 & 90.68 & 95.71 & 91.79 \\
\hline Total & 194,377 & $17,996,908$ & \begin{tabular}{|l|l|} 
& $18,166,639$
\end{tabular} & $36,163,447$ & $1,778,460$ & 506,578 & $2,284,938$ \\
\hline
\end{tabular}

Previous studies have focused mainly on Islamic seminaries through a sociological lens; however, none of the existing research has focused explicitly on English language education in two types of Islamic schools in Bangladesh. The current work substantively contributes to the field of Islamic schools as this research examines English teaching and learning in Qawmi and Alia Madrasas. It discusses the graduate skills that are required and highly esteemed in a market-based economy (Bano, 2010). This study also mirrors on prevalent assumptions of religious education's purposes and their potential relevance for social progress. Therefore, examining the English teaching and learning in Qawmi and Alia Madrasas is the main objective of this paper. As such, the study's research question emphases on two types of Islamic schools' education in Bangladesh and is depicted as follows:

What sorts of English teaching programs and up to which grade the Qawmi and Alia Madrasas learners in Bangladesh should impart for securing positions within government and sustainable educational developments?.

\section{Global significances}

Since 1971, Bangladesh has experienced a significant transformation which is resulted from globalization due to economic growth. The secular subject English is a fine example which was once a means of exclusion, is today regarded as a means of inclusion (Graddol, 1997). In this respect, Rahman et al. (2019) claim that the worth of English in the world is enormous and English teaching program in Bangladesh has become subject to a prime concern to maintain economic growth as well as developing a skilled workforce. The Prime Minister of Malaysia, Dr. Mahatir Mohamad, argues that: "it is English, which is a universal language, a language of information and wisdom. In order to gain knowledge, learners must acquire English, he further reasons". The daily Newspaper, Sun on December 23, 2018, quoted him, "To learn science as well as medicine, we need to have a good grasp of English". Held et al. (1999) claim that specific languages spread across increasingly large areas of knowledge as well as territorial jurisdictions of the globe and this is worth mentioning in the case of English, which has farreaching values. Given the massive changes in the socio-economic situation in the kingdom of Saudi Arabia in recent years, there has been a demand for a stronger English as a Foreign Language (EFL). To that effects, Saudi educators and members of the public servants frequently projected numerous resolutions (Alotaibi, 2014) aiming to communicate with the approximately 12 million Muslims who visit Kingdom of Saudi Arabia for performing Haj every year. Moreover, learning English is considered a religious imperative as of its importance in teaching Islamic values to non-Arabic speakers and thus participating in spreading the religion (Rahman \& Alhaisani, 2013). Nashruddin (2015) noted that English is needed to communicate Islam to other people around the globe both to Muslims or non-Muslims. Teaching English has become 
increasingly significant in Islamic education. The mastery of English can foster the critical literacy of the learners at Madrasa, and prepares high qualified graduates as future Muslim generations, he argued further. Robinson (1996) argues that a wide range of abilities and knowledge that Muslim might need to make the learners socially useful and to open the reasoning based academic domain. The knowledge of secularization is to adjust to a society with religious values laced with the adoption of non-religious principles (Asad, 2003) and the educational institutions, generating and transmitting knowledge are considered as the vehicle of secularization (Feldman \& Newcomb, 1969).

\section{Functional requirement of English}

In Qawmi Madrasa schools, after grade 8 and up to Dawra-e-Hadith (Master's level), Madrasas across Bangladesh impart only religious subjects, for example, the Holly Quran, Arabic grammar and syntax, the Hadith, Quran commentary, rhetoric, Urdu, Fersi, the Islamic law, jurisprudence and others. More attention is paid to the life of the prophet, history of Islamic life, Islamic rules and advice. The tendency of this educational system is revivalist. After grade 8, the learners of Qawmi Madrasa impart no secular subject while the students of Alia Madrasa and public school impart secular subject, for instance, English up to grade 12 (Higher Secondary Certificate). The students of Qawmi schools teach English focusing conventional grammar while the students of Public school and Alia Madrasa impart communicative grammar and literature. The Qawmi learners should follow the public schools up to grade 12. Despite few reforms taken place in Qawmi Madrasas, there are adequate space for education system reform, curriculum development that can help bridge several gapsbetween Qawmi Madrasa authority and policymakers. As educating the next generation of society is an essential part of achieving sustainable development in the developing world. English is also required to communicate through reading, writing, listing and speaking with target audiences. What is more, to communicate with native and non-native live audiences by arranging International Islamic seminar, Friday sermon, and oratory in public across the world?.

Universities in Bangladesh, for example, Dhaka University conducts admission tests at an undergraduate level every year. The learners who have 200 marks in the English subject at the Higher Secondary Certificate (HSC) after completing 12 years of schooling with the required grade point average (GPA) are considered eligible for admission to the desired undergraduate course based on written and vivavoce examination. In the written exam out of 120 marks, comprising 30 marks in the English subject. The students hail from general schools and Alia Madrasa are eligible for this kind of admission in the undergraduate level. However, the learners from Qawmi Madrasa are not eligible for securing the admission test as they do not have English subject up to Higher Secondary level. At the same coin, Bangladesh Public Service Commission conduct Bangladesh Civil Service examination, and recruited government officers every year. They deposit Secondary School Certificate (SSC) and Higher Secondary Certificate (HSC) as well as undergraduate and graduate certificate. Only the top degree is recognized by the government, however, other levels are not recognized by the Ministry of Education.

Regarding the prospects for obtaining a job in the civil service or admission into a public university, students from Qawmi Madrasas are disadvantaged as this education system is not officially recognized. 
The curriculum of Alia and Syllabi of Qawmi Madrasas

Table 3. The curriculum of Alia madrasa

\begin{tabular}{|c|c|c|c|c|}
\hline Grade & $\begin{array}{l}\text { Mainstream } \\
\text { equivalent }\end{array}$ & $\begin{array}{l}\text { Duration } \\
\text { (years) }\end{array}$ & $\begin{array}{l}\text { Type of } \\
\text { study }\end{array}$ & $\begin{array}{l}\text { Optional } \\
\text { subjects }\end{array}$ \\
\hline Ebtidai & Primary & 5 & $\begin{array}{l}\text { General } \\
\text { and } \\
\text { religious }\end{array}$ & $\begin{array}{ll}\text { Urdu } & \text { and } \\
\text { Persian } & \end{array}$ \\
\hline Dakhil & Secondary & 5 & $\begin{array}{l}\text { General, } \\
\text { science, } \\
\text { Hifzul } \\
\text { Quran }\end{array}$ & $\begin{array}{l}\text { Urdu, } \\
\text { Persian, } \\
\text { Hadith }\end{array}$ \\
\hline Alim & $\begin{array}{l}\text { Higher } \\
\text { secondary }\end{array}$ & 2 & $\begin{array}{l}\text { General, } \\
\text { science }\end{array}$ & $\begin{array}{ll}\text { Urdu } & \text { or } \\
\text { Persian } & \end{array}$ \\
\hline Fazil & Bachelors & 3 & $\begin{array}{l}\text { General, } \\
\text { science }\end{array}$ & $\begin{array}{l}\text { Either Urdu } \\
\text { or Persian }\end{array}$ \\
\hline Kamil & Master's & 2 & Theology & \\
\hline $\begin{array}{l}\text { Source: I } \\
\text { Note: G } \\
\text { and Mat }\end{array}$ & $\begin{array}{l}\text { ercer et al. ( } 20 \\
\text { neral includes }\end{array}$ & $\begin{array}{l}\text { 6) } \\
\text { engali, En }\end{array}$ & h, Scien & Social Science, \\
\hline
\end{tabular}

On the other hand, in a Qawmi religious school, seven stages of learning occur across Bangladesh. After carrying out the pre-primary grade, learners then move to the primary stage. Students are also imparted some basic Bangla, English, Mathematics, and Islamic history. After ten years of schooling, learners then move on to Mutawasita (Secondary School Certificate) and then to Sanunia Ulya (Higher Secondary Certificate) level. By then, students should have a sound knowledge of the Quran and its interpretations and have memorized hundreds of Hadith and their origins. They also learn Islamic Law and jurisprudence, Islamic philosophy and history, learn logic and Holly Quran, Hadith, and others across Bangladesh. Several students would move to the next stages of higher education both Fazeelat as undergraduate and Taqmeel (Dawra-e-Hadith) as Master's levels. Qawmi madrasas, up to date, deal 12 subjects, including five general subjects at grade eight. After this very grade up to Dawra-e-Hadith as Masters' level, they convey only the Islamic subjects.

On the contrary, in Alia Madrasa and general schools, both are dealing with secular subjects, including English up to undergraduate level. It means that the basic religious subjects and secular skills are taught at a different level in Qawmi religious schools.

\section{English practice at Qawmi and Alia Madrasas}

Given the English syllabi, Qawmi Madrasa learners impart filling in the gaps using appropriate words, word meaning, sentence making, whereas the Alia Madrasas institute filling in the gaps with clues, using suitable words with appropriate suffixes, prefixes or both, changing sentences, turning a passage into indirect speech, paragraph writing with clues and other skills.

Considering the Qawmi Madrasa syllabus, persuasive, creative, exploratory, and argumentative discourse are commonly absent, yet these are critical for students to discover many things. Qawmi students mainly practice topics ranging from reading comprehension to conventional grammar and paragraph writing to letter writing. In addition to learning Islamic issues, the pupils at Alia Madrasas principally study versatile secular lessons. So, Qawmi learners primarily focus on the study of orthodox principles.

\section{Analytical framework}

Secularisation discourse analysis is relevant to the scholarship of Robinson (2005), Uggla (2017), Hanegraff (2000), Hall \& Gieben (1992) and Asad (2003) as it concerns the relationship between reformation and practices of English education in Madrasas (Islamic seminaries). The ultimate motivation of this study is the transformation of knowledge between the religious and secular forms of the two types of Madrasas in Bangladesh. Here, Robinson's (1996) proposition of secularising Islamic schools has mainly been encouraged. Uggla (2017) and Hanegraff (2000) have primarily facilitated the analytical framework of this current study of Islamic schools in general and the Qawmi Madrasas' education in 
particular in Bangladesh. Secularization, the transformation of knowledge (Robinson, 1996), should proceed in a non-binary way (Bano, 2014 \& Uggla, 2017). As such, I would like to sum up an adaptive analytical framework that has mainly been termed "non-binary adaptive secularisation". The entire framework shows in Figure 1.

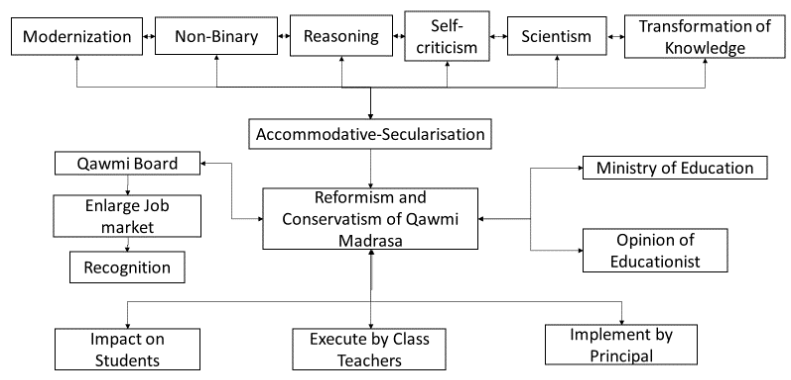

Source: Created by the author, based on literature review and fieldwork 2018

Figure 1: Analytical Framework

\section{Method}

This current study employs a qualitative approach with the aim of attaining an in-depth picture of English teaching and learning at grade 8 level development in two types of Islamic schools: Qawmi and Alia in Bangladesh. Based on ethnomethodological research, I chose a field site where this study was primarily carried out across eight Qawmi Madrasas (Islamic seminaries) and five Alia Madrasas located in the southern region of Bangladesh, from September to October 2018. Unlike Alia religious schools, Qawmi religious schools do not offer coeducation; therefore, only male students could be interviewed. Questionnaires focused on the changes in the curriculum and the present system and environment of English education.

In contrast to the Alia Madrasas, the Qawmi Madrasas located in the southern region are managed by a principal who is a follower or successor of a spiritual mentor and guide (peer).
I focused on the stronghold, the Barishal division (Southern region) with the aim of understanding the Qawmi Madrasa tradition. I also focused on conducting interviews with noted scholars of Qawmi Madrasas and prominent Islamic thinkers of Alia Madrasas, because they were considered the best advocates of their respective traditions. Regarding the research ethics, I ensured the protection of the anonymity of the participants in this research.

The literature review (Riaz, 2010; Asadullah \& Chaudhury, 2010; Bano, 2014; Asad, 2003; Robinson, 1996; Uggla, 2017; Hanegraaff, 2000; Hall \& Gieben, 1992; Zaman, 2014 and Metcalf, 1990) articulated the research question and enabled me to develop semi-structured questionnaires. I conducted participatory observation, of everyday life in order to understand how students and agencies feel the necessity of English, feel reform pressure to impart English and future effort of their life course. It is key to ethnographic research. Observation has mainly been characterized as the basis of all research methods in the social and behavioural sciences (Adler \& Adler, 1994) and as the backbone of the ethnographic enterprise (Werner \& Schoepfle, 1987). Even studies based on interview directly employ arguably observational practices in order to note-taking of body language as well as other gestural signals that lead meaning to the words of the informants. There has been an expectation that "participant observation" would lead to human understanding through field-workers learning to see, think, feel, and sometimes even behave as an insider or native. I kept field notes of everyday events, recording them along with the participants' viewpoints. I took part in many social and religious activities. For instance, I participated in Janazah (funeral) prayer at the premise of a Qawmi Madrasa. I ate breakfast and lunch with the classes, took photographs, attended prayers, classroom activities, joined 
Islamic seminaries and Mahfil. I visited the computer rooms, the libraries with the head of the institution.

Qawmi madrasas are considered a rigid zone. They normally do not allow anyone to communicate with their students. I convinced the principal of the targeted school by using my previous relations with them when I was appointed as a chief executive officer of this region. I have acquaintance with the head of the institution, and he allowed me to his Qawmi madrasa. Principal permitted me to visit specific classes, for example, grade 8 , to collect research data. As after class 8, general subject, for instance, English is not imparted at Qawmi madrasa. Grade 8 is the highest level in case of imparting general subject. Also, I chose the students of grade 8 level as their understanding level is mature enough. This study found that some students were senior, and some were junior across the same class. This is due to the fact that they learned the Holy Quran first and then enrolled in the Madrasa. As such, children of the same grade were in different stages of development across the regions. At first, I talked to the appointed student by the authority of the Madrasa. After that, I generated a good relationship with that student. He introduced me with his other classmates. Here, the first student became a local guide for me. By following this process, I talked to the total eightgrade class almost. Regarding this ethnographic interview time, I didn't face any sorts of intervention by the teachers and head of the institution. As I earned trust, they allowed me and talked to me in this research purpose. Considering the relevancy in this research, I selected students of grade 8 level.

I collected a range of information from different agencies through auto-ethnography. Auto-ethnographic writing can serve as a vehicle for thinking about new sociological subjects and forming new social parameters (Clough, 2000, p.290). In the critical analysis discussion, I use pseudonyms to conceal the interviewees' identity, and Madrasas remain unnamed in this current paper.

The interview data were organized on the basis of themes (Karim \& Mohamed, 2019). I decided to use only certain parts of the written documents that were closely connected to the research question.

\section{Results and Discussion}

According to this research methodologies, it is possible to analyze this research data. The author is familiar with the ways in which the data collected through ethnographic study. The author knows in which ways those patterns can be explained. Most of the data is likely to be in narrative (Angrosino, 2007) form (i.e., the result of in-depth interviews, observations). Due to this reason, the author continuously analyzed, interpreted, and learned from practical datakeeping interpretaive process and narative form in mind. I learned a great deal from the field research aimed at answering my research question as I started reading through my empirical data (Gay \& Airasian, 2003). After several readings, I started to make notes on the texts and pay attention to tracing connections, and similarities or contrasts. Then, I wrote an analytical memoranda about these issues. The study has learned many things from the field, aiming to answer the research questions.

\section{Students' interview results}

On the basis of the objective as well as research questions, I secured evidence from respondents at Qawmi Madrasas and Alia Madrasas located in the southern region of Bangladesh. The ultimate goal of this current study was to examine English teaching and learning in the two types of Madrasas. I went through the English syllabi of both types of 
Madrasas and found problems in them due to the gaps in English teaching and learning. Communicate grammar is completely absent in the Qawmi schools, and the learners practice only conventional grammar, for instance. I conducted interviews with learners on issues such as class size, second language practice, use of modern technology, learners' job prospects, pursuing English in higher education, and the present syllabi of two types of Madrasas. I analyzed the learners' insights and found numerous deficiencies in the present practices of conducting classes. A fine example is extra-large classes and too short time allocation. Concerning class duration and class size, Mazid, a learner in grade 8 at a Qawmi Madrasa, mentioned:

We have large classes. We sleep at night in the same classroom on the floor across the year. In seven days, in this Madrasa we have an English class for only two days, and the duration of the class is only 30 minutes.

Researchers believe that small class size provides abundant facilities for the learners and teachers aiming to undertake the highest level of language achievement. Kasumi (2015) argues that classes with a small number of students tend to be more fruitful than classes with a large number of students. Students of the Qawmi religious school also mentioned that they are increasingly getting stress for memorizing religious lessons. In this matter, Asadullah and Chaudhury (2010) note that "students in Islamic seminaries memorize various religious written documents while they get little room for serious thinking". However, pupils from the Alia Madrasas mentioned different matters about their class environment as well as class duration, such as: 1) Our English class duration is one hour. Additionally, our class size is not large. We have a different room for staying at night. Thus, we enjoy a conducive environment. 2) This elucidation displays that learners from Alia Madrasa schools enjoy a healthier environment as well as longer class duration than their counterparts at Qawmi Madrasas. 3) MillerWhitehead (2003) depicted that "small classes fuel teachers' pretty potential spirits at the same time, decline the most discipline issues".

Some interviewees mentioned that the English syllabus of Qawmi religious school does not meet the current needs of pupils. They emphasized as follow:

Regarding the prospects for obtaining a job in the government service and admission into a public university, we (Qawmi Madrasas) are having disadvantages as we do not have a secular subject, English in the syllabi after grade 8 .

It is worth mentioning that entry into the civil service is critical as well as to gain admission to a public university as a graduate who gains university admission will secure positions in the market economy (Bano, 2014). In both cases, English skill is essentialized. "Qawmi madrasa learners are engaged in the mosques and madrasas, which is not connected to the financial market" (Asadullah and Chaudhury, 2010). Most students wanted to pursue English as a subject as it contributes them educational, social and economic privileges. Considering this result, one Qawmi student, Rabiul, age 19, who intended to learn English with the assistance of cutting edge technology, depicted and other students supported that they were not getting the chance to learn English through technology. As he mentioned:

We do not have the scope to learn English by using leading-edge technology.

Nevertheless, the learners of Alia religious schools can have abundant scope to keep practising by utilizing leading-edge technology in their class or computer lab.

Jorge et al. (2003) mentioned information and communication technology (ICT) tools are 
useful. Morgan (2001) claimed that "modern technology is valuable and carry sustainable results". Studies (Jimoyiannis, 2010; Lu, Tsai, and $\mathrm{Wu}, 2015)$ have found that the integration of technology in the classrooms contributed potential outcomes and cultivated major benefits to students and teachers alike. The student's results indicated that it was challenging for pupils in the Qawmi school to have the chance to use modern technology.

When I asked the learners about the problems they confronted in learning English, one schoolchild, Mannan, aged 18, from the Qawmi school, remarked:

I cannot comprehend English. Likewise, I am unable to read and write sentences.

However, students from Alia religious schools mentioned different matters regarding their English lesson. In conversation, Bashir, a grade 8 student aged 16 from Alia Madrasa, told:

We practice communicative grammar and study literature. We have plenty of scopes to use the computer lab where we use our website, read the different academic piece of written documents, listen to many valuable speeches. Besides our class, we learn every day.

Based on the learners' opinions and the syllabi of English, I concluded that the Qawmi Madrasa students mainly practice conventional grammar while the Alia Madrasa learners practice communicative grammar as well as literature. Richards \& Rodgers (2014) maintain that task-based activities, role play and reproduction are required to support classes where the communicative language teaching approach is employed. Equally, any task that requires learners to speak besides listening to others entails the use of communication (Moss $\&$ Rose-Feldman, 2003).
The research results showed that it was challenging for the pupils of Qawmi Madrasas to have the opportunity to use the cutting-edge information technology while the students belong to Alia Madrasas keep practising with leading-edge technology. Integrating information and communications technology tools in teaching and learning situation can lead to fuel learners' learning abilities (Jorge, Jorge, Gutierrez, Garcia, and Diaz, 2003). In their English lessons, the learners exercise mostly traditional grammar, which is not complete and adequate. In comparison, their counterparts in Alia schools practice communicative grammar and are imparted communicative language skills. Bano (2014) reasons that Qawmi graduates do not have extensive experience in subjects that are commonly regarded in order to contribute global economy and modern knowledge systems.

\section{Teachers' interview results}

In this current study, I interviewed Alia and Qawmi Madrasa teachers about the syllabi, curriculum reform, teacher training for L2, teacher salaries and others. Regarding the Qawmi religious teaching, most of the interviewees remarked that Qawmi Madrasas are mainly focused on religious subjects. At the same time, they neglect secular issues, for instance, English chiefly. One of the teachers, Farid Uddin, aged 61, who completed his Dawra-eHadith as Master's level mentioned the following:

The syllabus formulated for the pre-school to grade 8 in Qawmi religious school does not have science as a subject.

Science education is completely ignored in Qawmi schools. His opinion signposted that the importance of science education cannot be felt by the Qawmi Madrasas.

On the other hand, Alia Madrasa imparts secular subjects, for example, English, 
Mathematics, science and others up to undergraduate level. Mufti Ziaul, aged 50, a teacher who had graduated from an Alia Madrasa, made the following points:

In the Alia Madrasa mixed learning is provided. Learners institute secular subjects (English, Mathematics, science, social science) laced with Islamic subjects (Holly Quran, Hadith) up to undergraduate level. But, at the Master's level, the learners impart only Islamic subjects.

Reiss (2013) mentions that the key aim of science education is to enable students to realize how science is undertaken and to learn about its prime contributions to knowledge. It is vibrant that Qawmi learners are parted from certain key values, for example, argument, scientism.

Insufficient teacher training chances were another vital finding from the discussion with teachers. Many Qawmi teachers mentioned they had not been effectively trained to focus any subject in their religious schools and beyond. Mufti Habibul, age 59, who had graduated from Qawmi Madrasa, remarked the following:

We did not receive any subject-based training, for instance, English and professional development training.

However, teachers of Alia Madrasas said they had imparted adequate training from the government training institutes. For example, Tareq, aged 54, a teacher of Alia school who had completed his Master's from public University, depicted:

Every year we impart scores of training range from subject-based in-service training, ICT subject training to professional development training.

The study's findings revealed that no Qawmi teacher received any in-service training for subject-based teaching and ICT subject training from any training institutes. It is indispensable for teachers be amply trained on how to effectively and efficiently use ICT in the classrooms to design technology-based lessons and to be precise be more familiar with the multifaceted nature of technological inventiveness (Lim, 2007; Aslan and Zhu, 2018; Jimenez, 2005). Bangladesh Madrasa Teachers' Training Institute (BMTTI) was established in 1995 to train only Alia Madrasa teachers. It works for the development and modernization of Madrasa education. The training institute offers a four-week course on 'Communicative English Language.' However, teachers from Qawmi religious schools have no opportunity to participate in the mentioned course. By attending such training programmes, teachers learn a range of significant academic activities through pair work and group work: fundamental concerns of communicative English (Karim \& Mohamed, 2019).

I asked teachers in both types of Madrasas about their salaries and other resources. Teachers from the Qawmi Madrasas were very upset regarding these matters. They revealed the following points:

In the Qawmi religious schools, we get a minimum salary.Our salary ranges from 3,000 to 9,000 [Bangladesh Taka(BDT) monthly].

Considering the statement, it is adequately clear that the monthly salary of these teachers is not sustainable. Prospective pay and supplementary perks are presumed to attract higher quality graduates to teaching and to assist in retaining them.

Nonetheless, teachers of Alia religious schools cultivate high pay and the associated benefits than those in Qawmi religious schools which indicated in this study. A teacher of Alia school, Tarequl Islam, aged 52, who graduated from Alia Madrasa, commented: 
In the Alia Madrasa, we get adequate salary as well as other resources from the government.

The findings reveal that the monthly salary of Qawmi Madrasa teachers is unsustainable, whereas the Alia school teachers receive a government salary and other facilities. The study's findings disclose that no Qawmi teacher had received training in subject-based teaching from government training institutions while the Alia school teachers had received adequate subject-based in-service training and professional development training from these institutions. Such training provides teachers with new abilities and strategies with communicative activities (Chowdhury \& Kabir, 2014). Wallace (1991), who developed the reflective cycle, argues that teachers can reflect what they have learned by participating in training programmes. The findings of this study revealed that in-service training with adequate public funding is necessary for Qawmi Madrasa teachers.

\section{Principals' interview results}

Alia madrasa imparts secular and religious knowledge to produce skilled graduates. Some Qawmi Madrasas have extended their general syllabi. However, the curriculum is still not adequate as mentioned by one of the English subject teachers, Abdur Ragib, aged 57, who holds a master's degree from an Alia madrasa: 1) Qawmi religious schools have done some reforms so far into their curriculum; 2) Nevertheless, these are far from adequate and should be updated.

Researchers have not been able to understand the contents of learners' textbooks of that Qawmi religious schools, with these textbooks not recognized by the Ministry of Education in Bangladesh (Bano, 2014). This situation, without changing of syllabus, will not help Qawmi graduates to get a job in the civil service or get admission in a public university as they have been taught principally religious subjects, while students who have attended Alia religious schools have been taught other secular subjects up to undergraduate level and merely religious subjects in the graduate level. Metcalf (1982) found that throughout Muslim history, religious reform movements have transformed not only belief but also social and political life. one of the senior teacher, Abedin Naser, aged 54, mentioned as follows:

The reforms, to date, have been mainly done in the Qawmi religious schools resulted from the internal pressure (students, teachers, caregivers) and possibly external force (government, globalization, social agents).

This study found that in the Qawmi school's general subjects are being ignored and that the reforms undertaken by Bangladesh Qawmi Madrasa Education Board are far from adequate in meeting the present demand of society at large.

Teachers in both types were asked about the problems faced by learners in learning English. Most teachers in Qawmi religious schools mentioned that students lacked practice, technology, and English subject teachers, while the Alia religious schools' teachers said that students lacked practice.

As far as the teachers' salary and school environment are concerned. The study asked teachers about teachers' salary and the school environment. They mentioned: 1) In our religious school, we get a government salary. 2) Moreover, our school environment for learning is conducive.

The study noted that teachers in the Alia religious schools received a comparatively better salary, and the learning environment is more advantageous than the Qawmi religious schools. Likewise, the former also has received bountiful 
other resources for their teaching and learning process than the latter.

During the interview, principals of both types of religious schools were asked about English teaching-learning environment, curriculum reform, teacher training and the others. Principals of Qawmi religious schools were asked about the importance of training for teachers on English. Principals from Qawmi schools were expressed that the increasing presence of English in Qawmi schools would have no adverse influence on religious practices. Some interviewees in both types of schools have extended the argument that anti-English attitudes in Bangladesh were a historical mistake that had resulted in Bangladesh, as well as Muslims in India, lag in economic development. One of the principals from Qawmi religious school, Mawlana Abdur Rashid, aged 65, who had completed his Dawra-e-Hadith, made the following comment: 1) Muslim in the British period thought that if they learned English, their religion would be affected, and they would become Christian. 2) As a result, Muslim isolated themselves from learning of the secular subject, English.

Regarding teacher training, most principals said this sort of training is contributory to fuel teachers' professional development, and its absence impedes the professional growth of teachers and actual achievement levels (Eduwen, 2016). In 1974, the first education commission was formed and gave English priority as a foreign language. In the same coin, the recent National Education Policy enacted in 2010 emphasized English education. This was commented by a principal from Qawmi religious school, Mawlana Mohamad Rauf, aged 69, who completed his Dawra-e-Hadith from India, as follows: 1) The National Education Policy 2010 highlighted importance on the English language; 2)What is more, our Qawmi curriculum should be updated to the social as well as Global demand all ways.
Regarding enable students to get admission into a public university or to secure a government job is highly unlikely for Qawmi graduates.

Considering the importance of this general subject in both global and local settings, policymakers need to enable the reform of the syllabus to address the existing gaps in Qawmi religious schools. "Curriculum reforms (Chowdhury and Kabir, 2014) are necessary for the sustainable educational future for the pupils". On the other hand, principals in the Alia religious schools were more highly qualified than those in the Qawmi religious schools. Alia Madrasa teachers can take part in in-service training. This sorts of training provided by government institutions. As stated by one principal, Ajharul Islam, aged 54, who completed his Master's degree from Public university: 1) Teachers in the Alia religious schools get training from the government institutions; 2) Any types of training, for instance, Continuing Professional Development1; 3) Continuing Professional Development-2 and subject-based training and others; 4) The Alia religious School teachers merely receive these types of training.

The finding revealed that the given training was immediately needed for Qawmi religious teachers. Teachers should be given training and other resources for their educational development and should gain more confidence. Unlike Qawmi religious schools, Alia religious schools have conducive teaching-learning environment which they mentioned.

This study covers one region, the southern region of Bangladesh. Hence, it does not cover Bangladesh's whole Madrasa education landscape. Only males could also be interviewed, as co-education is absent in these Qawmi religious schools. It can be focused in future studies by targeting female interviewees. 
Three sets of questionnaires were used: questionnaires for students, teachers, and principals on the basis of the motivation of this study, When the data of all three questionnaires were combined, I had gathered a wide variety of information from the respondents about teaching and learning EFL in Qawmi and Alia madrasas. Observation and the contents of the questionnaires are pivotal for the present study, as they have a direct relationship to the research questions and objectives.

\section{Conclusions}

This study examined the secular subject and the reforms that the religious schools, Qawmi, in particular, have undertaken and investigated whether their English syllabi provide the ability to compete for critical portions of the civil service examination that are arguably managed in English in Bangladesh. Moreover, whether their English syllabi met the admission requirement at the undergraduate level of public universities. The study found that the Qawmi syllabi prevent the graduates from getting admission to the public university and subsequently taking a position in the civil service in Bangladesh. This study enhances our understanding of the significance of offering English subject in religious schools, Qawmi to be specific to boost learner well-being and holistic development. Thus, secular subjects, and especially English, that are relevant to the job market are immediately required and should be included in the curriculum of these religious seminaries.

Weber's (1990) leading scholarly concern was accepting the processes of secularisation and rationalization that he associated with the rise of capitalism and modernity. He also found these as the result of a new way of thinking about the world at large. This paper also shows that learners, teachers, and principals believed that Qawmi Madrasas had a less conducive environment for English learning as opposed to Alia religious schools. English class duration and schedules were not sufficient in the Qawmi religious schools compared to the Alia part. Teachers' salaries and other resources were insufficient in the Qawmi religious schools, whereas the Alia religious schools provided better wages and other resources. Teacher training for the English language was enormously necessity in the Qawmi religious schools. This training was needed to develop teachers' skills in teaching methodologies and strategies. New technology was identified in this study as an essential item for learners to cultivate their language development. Also, learners in the Qawmi religious seminaries claimed that the resources used in the classroom, such as English textbooks, should be implemented more effectively.

Given that establishing a Qawmi Madrasa Teaching College would be pivotal for professional development in English language teaching. The conducive environment should be provided in the Qawmi madrasas, while the duration of English classes and regularity of their schedule should be enhanced. Teacher salaries and the quality of teacher various training and essential resources should be fueled for the Qawmi type of schools. Lastly, this study supports the recommendation that English should be taught up to the graduate level in both types of religious schools as part of their daily program to address the concerns sourced from teachers and students of the particular schools.

\section{References}

Adler, P. A., and Adler, P. (1994). Observational techniques. In N. K. Denzin \& Y. S. Lincoln (Eds.), Handbook of qualitative research (pp. 377-392). Thousand Oaks, CA: Sage.

Angrosino, M. (2007). Analyzing ethnographic data. Sage publication. 
Asad, Talal. (2003), Formations of the Secular: Christianity, Islam, Modernity. Stanford: Stanford University Press.

Asadullah, M.N., and Chaudhury, N. (2010), Religious schools, social values, and economic attitudes: Evidence from Bangladesh. World Development, 38(2), 377-394.

Asadullah, Mohammad. Niaz., Chaudhury, Nazmul., and Josh, Syed Rashed AlZayed. (2009), "Secondary School Madrasas in Bangladesh: Incidence, Quality and Implecations for Reforms, Human Development Section, South Asia Region, World Bank.

Aslan, A., and Zhu, C. (2018), Staring teachers' integration of ICT into their teaching practices in lower secondary schools in Turkey. Educational Sciences: Theory \& Practice, 18, 23-45.

Bangladesh Bureau of Educational Information and Statistics [BANBEIS], (2016), Ministry of Education, Dhaka.

Bangladesh Bureau of Educational Information and Statistics [BANBEIS], (2017), Ministry of Education, Dhaka.

Bano, M. (2014), Madrasa reforms and Islamic modernism in Bangladesh, Modern Asian Studies, 48(4). 911-939.

Chowdhury, Raqib., \& Kabir, A. H. (2014), Language Wars: English education policy and practice in Bangladesh. Multilingual education, 4(21), 1-16.

Eduwen, F. O. (2016), Inservice training for trainers: Overview, problems and the way towards.The Journal of Education and Practice. 7(26), 83-87.

Gay, L., \& Airasian, R. (2003). Educational Research: Competencies for analysis and applications, Merrill.
Hall, S and Gieben, B. (1992), Formations of Modernity. Cambridge: Polity Press.

Held, D., Mc Grew, A., Glodblatt, D., and Perraton, J. (1999), Global Transformations: Politics, Economics and Culture. Cambridge, Cambridge University Press.

Jorge, C.M.H., Jorge, M, M. Del C. A., Gutierrez, E. R., Garcia, E. G., and Diaz, M. B. (2003). Use of ICTs and the perception of e-learning among university students: A differential perspective according to gender and degree year group, Journal of Interactive Educational Multimedia, 7(2). 13-28.

Jimenez, A. B. (2005), The rural school and its teaching staff facing the challenge of the advancing information and communication technologies, Annual Proceedings of Vidzeme University College "ICTE in Regional Development", 8-11.

Jimoyiannis, A. (2010), Designing and implementing an integrated technological pedagogical science knowledge framework for science teachers professional development. Computers \& Education, $55,1259-1269$.

Lim, C. P. (2007), International Review: Effective integration of ICT in Singpore schools: Pedagogical and policy implications, Education Tech Research Dev, 55, 83-116.

Lu, C., Tsai, C. C., and Wu, D. (2015), "The Role of ICT Infrastructure in Its Application to Classrooms: A Large Scale Survey for Middle and Primary Schools in China. Educational Technology \& Society, 18(2), pp. 249-261.” 
Metcalf, Barbara D. (1982), Islamic Revival in British India: Deoband, 1860-1900, Princeton: Princeton University Press. National Education Policy. (2010), "Ministry of Education", The People's Republic of Bangladesh.

Weber, Max. (1990), The Philosophical Discourse of Modernity, Polity Press.
Werner, O., and Schoepfle, G. M. (1987). Systematic Fieldwork: Vol. 1. Foundations of ethnography and interviewing. Newbury Park, CA: Sage.

Zaman, M. Qasim. (2002), The Ulama in Contemporary Islam, Custodians of Change, Princeton University Press. 